\title{
The Art of Science
}

\section{Making Things Popular with Scientific Journal Covers}

\section{Sven Grampp, Friedrich-Alexander University, Germany}

\begin{abstract}
So far cover pictures of scientific magazines have only been examined sporadically. This article is a humble attempt to improve this deficit. Especially cover pictures of the science journal Science will serve as examples. Following a system-theoretical foundation of my access, the central visualization strategies of the cover pictures of Science will be identified and their functionality evaluated. Three thesis statements shall be proposed within this.
\end{abstract}

First Thesis: On the cover of scientific journals a popular picture of (natural) science is designed which is meant to make a (natural) scientific approach especially attractive and communicatively accessible for recipients independent of concrete research contexts.

Second Thesis: Therefore a specific aesthetic is developed on the cover of scientific journals with recourse to the artistic avant-garde (especially of Pop Art and Minimal Art) and their visual form principles of seriality.

Third Thesis: Through the iconic and indexical foundation of these form principles a direct affecting of the recipient is targeted at in a special way.

Keywords: Scientific Journal, Cover Art, Science, Function, Icon, Index, Symbol, Affect, Hyper-Connectivity, Popular, Seriality, Similarity, Paratext, Aesthetics 
Every time I told my natural science colleagues about my plan to evaluate the covers of science magazines according to which picture of science they compose and what can be concluded from this about the self-image of natural scientists, they all reacted in a similar manner.Cordially but with firmness they explained to me, a member of the humanities faculty:No scientist ever cares about the cover of Science, and certainly not about the cover art. The readers of science magazines are solely interested in the research results explained in the articles.Further, one would never take the print version but read the articles online instead (this way at no point even seeing the cover). From this perspective a question naturally follows (and did in fact follow in many conversations): What point is there to researching the self-image of natural science based on the analysis of the magazine or journal cover?

Now, expecting that one would not want to drop their research plans despite such disappointing comments, there are at least two ways to respond: On the one hand, one could question the self-characterization of my colleagues since it is after all astonishing how much value is placed on the layout of the cover pictures (which, by the way, have a prominent place on the online platform as well; at least this is the case with popular science magazines such as Science or even nature). Why should one make such an effort when apparently the recipient will not even glance at the cover pictures? When you look at the amount of advice from scientists for scientists circulating the internet on how to spiff up your submitted texts with pictures or graphics in order to perhaps boost the article to a cover story it would only seem logical to view the pictures as potential cover art. Thus, one should despite all the denial give the cover the credit of having a function of guiding the audience's attentionwithin the science community (confer also Liang, 2013, 2014, Fitpatrick, 2012). On the other hand, one can also take the comments of my science colleagues seriously and search for the function of the cover to gain attention outside of the science community; namely in the popularization of natural science for an audience that does not consist of experts (e.g.Nelkin, 2001, Glasshoff, 2012 and especially Gigante, 2012). In this case a certain picture of natural science, a natural science self-depiction, is designed for "others".

In order to keep out of trouble with my science colleagues, I will concentrate solely on the second option in this paper. This means: first and foremost by analyzing the aesthetic design of several cover pictures of the science magazine Science, I want to verify a hypothesis which states: The science cover picture functions as a threshold where the discussion amongst the 
experts should generate fascination for (natural) science phenomena through specific visual designs and further excite recipients outside of the (natural) science research context.

\section{Framework: How to Analyze Scientific Journal Covers}

The modern society is known for being functionally differentiated. This is a common perception in sociology, at least in the constructivist and system theoretical area. Under these circumstances it is advisable to follow-up on this fundamental sociological perspective because through this a functional analysis of cover pictures of science magazines can be made appropriately.

The sociologist Niklas Luhmann has done multilayered extensive research in this theoretical field. His differential-theoretically founded model of evolution shall be presented from this research (cf. Luhmann, 2012,pp. 251-358). Luhmann sees one of the fundamental breaks within the evolution of society to be in the change from the stratisfactoric to the functionalsocial differentiation. In stratisfactoric societies there is a clear arrangement of people according to different levels within society. It follows there is a vertical hierarchy within the social structure (for example king - nobility - peasant/serf) and with this a functionality of these roles (the king rules; the peasant tends the fields etc.). With the early modern era the complexity of the living circumstances increased. From this a stronger necessity for organization and a constantly growing need for specialization and differentiation of all parts became inevitable. As a result smaller subsystems developed that each took over a specific function (economics for merchandise circulation, science for truth, art for beauty etc.) These functional systems-and this is new for the development of societies-now no longer operated hierarchical, but instead without an overall and coordinating central instance, adapting a separate system specific coordination based on auto poetic processes (the economy works with certain codes: buy/not buy, science uses the codes: true/false, art bases its decision on the difference: beautiful/ ugly etc.). Corresponding to this, the general possibility of participation in these different systems developed for everyone. In fact, it is becoming more and more difficult for members of modern societies to only participate in a singular system. Naturally a set of problems follows this development: How should the individual find his way in a world full of possibilities and specializations, act appropriately and participate successfully in each individual subsystem? Also, having to fulfill certain functionally specific entrance criteria (for example study physics, be wealthy or able to paint)? Changing the 
perspective also presents challenges. Not only the separate individuals have difficulties, but also the separate subsystems since there are such a variety of possibilities for the individual to use one's time otherwise. To that effect, the successful inclusion of an individual into a subsystem is less likely. On the other hand the separate subsystems are so specialized and the entrance barrier is so high that it is next to impossible for an individual to cross even if he is willing to participate. Without understanding the theory of relativity a career in astronomy becomes difficult.

To make participation more attractive the Swiss sociologist UrsStäheli argues that the separate subsystems react with specific forms of the popular (cf. Stäheli, 2005). Simple examples of such popularization in the area of science are open-house occasions at the university where lectures are held especially for school kids, experiments with spectacular explosions are shown or bags and brochures passed out with the university logo. According to Stäheli the popular itself is not a separated discourse area (like many cultural studies followers understand it) but a function for different subsystems to become more attractive to people who are (still) outside of asubsystem. Insofar the populartakes place on the periphery of each subsystem since it is not strictly bound to the system specific communication (in science it is not bound to the search for truth) and other aspects become more important (general comprehensibility and the generation of affectedness).Subsequently, the popular is seen as a threshold. Here the system specific communication is overstepped to reach a recipient outside the system in order to heighten their chances of connecting communication.

From this functionality based point of view the popular can take many different forms in each individual subsystem (spectacular experiments in science, orchestration of miracle healings in religion, marches in politics). However, in all these cases the popular has two dimensions that are active across all systems: “it'sgeneral comprehensibility (hyper-connectivity) and its affectedness" (Ibid, p.160; my translation). Hyper-connectivity, in this context, refers to a principle that instructs a certain operation, the "use of semantic forms that connect to a multitude of different contexts.” (Ibid; may translation) This way nearly every resident of Western Civilization knows what it means when somebody devoutly folds his hands; everybody knows the mysterious smile of the "Mona Lisa", most people can recognize a feminine statue with bound eyes and holding scales as the personification of justice. What is important is thatthese gestures and depictions can in fact originate from a certain subsystem 
(for example religion or art), but they are trans-systematically citable and functional since they are assumed to be familiar; exactly this makes them universally understandable. In turn, in this context, affectedness means: An immediate emotion is triggered, an affect (i.e. not merely a suggestive pointing to a certain meaning). It is efficacious. A spectacular experiment means something, for example that easily oxidized metals put together with oxygen react in a strong manner and through this an explosive flame is developed. Yet, the attractiveness of such an experiment is not usually found in the search for meaning, but rather in the immediate affect that comes from the explosive flame.Nevertheless, generally speaking, the creation of affects cannot be reduced to a semantic communication form; the affect is not about meaning. However, the creation of affects can be used strategically to structure communication-and this means in our case,to enhance the fascination for a subsystem.

Affectedness and hyper-connectivity are two dimensions of popularity that are not easily separated. In almost all cases popularization strategies operate in and with both dimensions. A concrete example where both dimensions are working is the cover of the "Special Report" from the magazine Time which was published on the $17^{\text {th }}$ of February 2003 on the occasion of the $50^{\text {th }}$ anniversary of the discovery of the DNA helix(cf. figure 1).

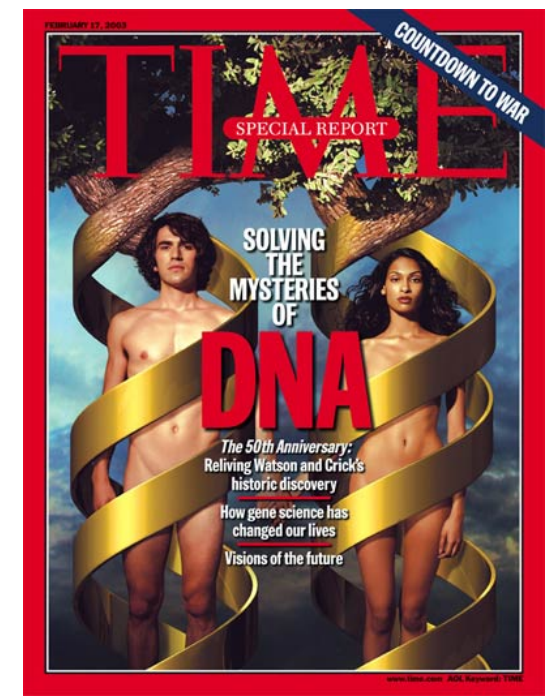

Figure1

According to NiklasLuhmann the circulation of the magazine Time falls into the system 'mass media' (cf. Luhmann, 2000). Luhmann maintains, this system operates with the basic 
code information/non-information i.e.the world is not primarily scanned for its truth (as in science), but for informative material, above all,new material (even referring to a common phenomenon such as the DNA helix). In order to make this new material understandable for as many as possible forms of the popular are used on the cover of the magazine. On the one hand hyper-connectivity is used here:forms are cited that can trans-systematically be assumed as common such as a naked man and woman being portrayed that are obviously in the iconographic tradition of Adam and Eve in paradise. We see two trees that in this context represent the two significant trees in paradise, namely the tree of knowledge of good and evil and the tree of life. Both trees have a helix-structure and the bottom half ends in a golden band that represents a DNA helix which the title of the cover again distinctly emphasizes. Adam and Eve in paradise as well as the DNA helix are semantic forms that are assumed to be commonly known by the public in the year of 2003, the year of publication of the "Special Report" and can accordingly be referred to for popularization purposes. The interlinking of both elements on the cover has a dual implication:1-With the DNA helix the program of life becomes visible. $2-\mathrm{We}$, the humans, become godlike since we are able to manipulate genetic information. This interpretation is assisted by the text printed on the cover.

On the cover one can also find aspects of the generation of affectedness: Ignoring the content and concentrating only on the formal visual representations illustrates the following: Firstly, the cover is structured by duplication that is ordered symmetrically-two humans and two trees that are all vertically aligned. Secondly, both vertical connections receive circling and plastic dynamic through the helix form. Thirdly, the bodies of both man and woman are naked; their skin is brightly illuminated and catches the eye immediately. Fourthly, both humans seem to be looking at us directly without their enigmaticgaze being clear to analyze. However one chooses to interpret these aspects, it is important to note,there are elements that stir affects beyond a semantic allocation, be it through nudity, mysterious gaze or by formalaesthetic construction like symmetry, or even spiral-shaped arrangement. Beyond that some of the affect allocations are in fact connected to semantic aspects of hyper-connectivity. For example, the spiral-shaped circling of man and woman as well as their nudity represent humans being at the mercy of their genetic make-up.

With this example I also come much closer to the actual subject of this paper, namely the cover pictures. Following the literary theorist Gérard Genette the cover pictures are a 
paratext (cf. Genette, 1997, p. 2 and p. 408). A paratext is a type of text that accompanies a (basic) text or even enriches it. In keeping with Genette'smétier, for example, an advertisement to a new novel is a paratext to the basic text 'novel' or likewise an interview with a playwright concerning his new work is a paratext to the basic text 'dramas'. But also a preface or even a cover are paratextual enrichments or additions to the basic text 'novel' or when speaking of magazines, to the articles in this magazine. ${ }^{1}$ The purpose of such a paratext is in the mediation between outside and within, the textual discourse and the beyond-textual world. The paratext receives a threshold-and mediation function. This refers initially to the concrete case of the cover. On the one hand, it is connected to the subject of the journal. Generally, the cover picture shows something closely related to the journal's unfolded content. On the other hand, the cover fulfills the purpose of generating attention for the journal; for instance by reverting to forms of popularization, in effect working with hyperconnective elements and generation of affectedness. In any case the cover adjusts the expectation towards an article, to the content as well in regard to the possible recipients (cf. Matthews/ Moody, 2007, p. 16; on the History of the Cover: ibid., p. 17ff.). The cover of a magazine has thus a three-way relation: Firstly it is related to the internal article, secondly to the possible external public, thirdly, it is the mediator which brings potential reader and article together or at least conveys an attractive image of the anticipated content to the potential reader. The paratext 'cover' is therefore a threshold where the textual discourse, in our case the natural scientific discourse (that amongst other areas takes place in the articles of the magazine Science), is brought together with the social world. Understood under the aspects of the above introduced systematic vocabulary and adapted to our specific example it is apparent: The paratext 'cover' of a natural science magazine such as Science is a central means for the popularization of the natural science subsystem. Through the cover the natural science discourse is opened and is meant to be made attractive for spheres beyond the scientific subsystem. Thus, shaping the expectation and guiding the perception of natural scientific research.

\section{For Example: The Cover Art of Science}

My particular research scope is on covers of the Science issues published between 2010 and 2013 all of which are also accessible online on the Science homepage (cf. Science Homepage, 2014). The natural science journal Science is a weekly appearing natural science professional periodical that next to nature belongs to the most important and frequently cited natural 
science magazines around the globe. The articles' main focus is on the category "Research". The articles within this area are all chosen through the peer-review principle. ${ }^{2}$ The publications cover the entire spectrum of the research done in natural science, but have an emphasis on genetics and biotechnology. In each issue one article (with very few exceptions) establishes the theme for the design of the cover picture. ${ }^{3}$ Quite frequently the pictures and graphics used for the covers come directly from the author of these articles or the designs were created or chosen in collaboration of the authors with the editorial staff (cf. for this Liang, 2003, Fitpatrick, 2012). But this connection of cover picture and article is not explained on the cover itself, but rather inside the journal, under the rubric: "On the Cover". 4 Actually it is rather noticeable that on all of these covers very little text can be found (see figures 2a-f). Merely the title of the magazine printed in big letters, graphically in the same writing from issue to issue and centrally placed on the top border, it announces what the magazine is about, namely "Science". Only above the title is there information about the issue number and date in small print. On the bottom either on the left or right side one can find the publisher-acronym "AAAS” (for "American Association for the Advancement of Science”) as well. Beyond that, the cover pictures are not semantically emphasized via text. ${ }^{5}$ This distinguishes the cover of Science fundamentally from other periodicals, such as Time or even Der Spiegel. In contrast to Science the previously mentioned example of the "Time Special Report" (see figure 1) clearly proclaims the topic with the help of text and specified: “SOLVING THE MYSTERIES OF DNA. The 50 ${ }^{\text {th }}$ Anniversary [...]." Such a linguistic anchor of the meaning of the picture is missing on the covers of Science (cf. for this linguistic anchor Barthes, 1977). On Science the pictures speak for themselves.

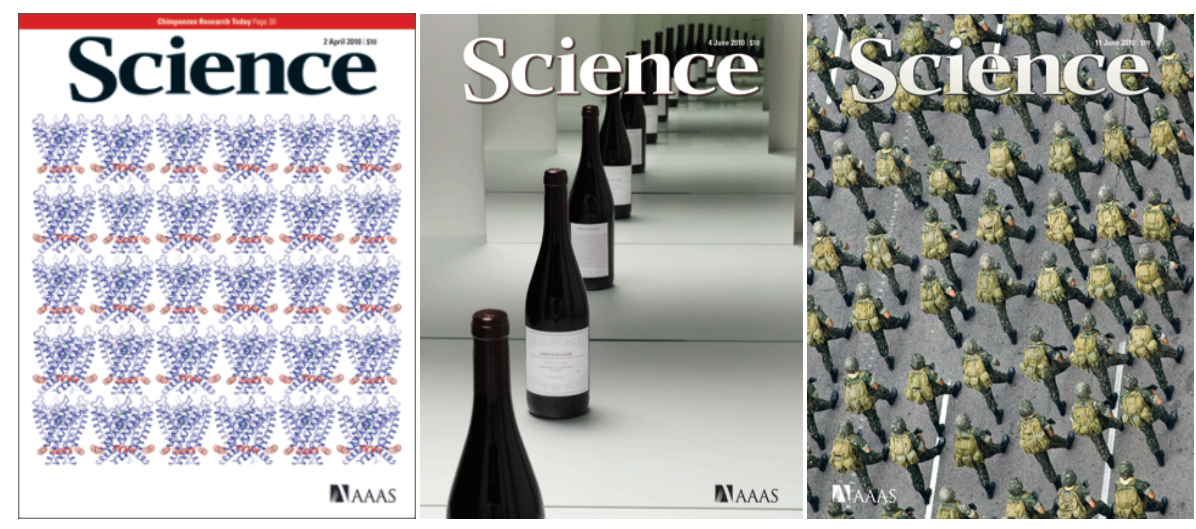



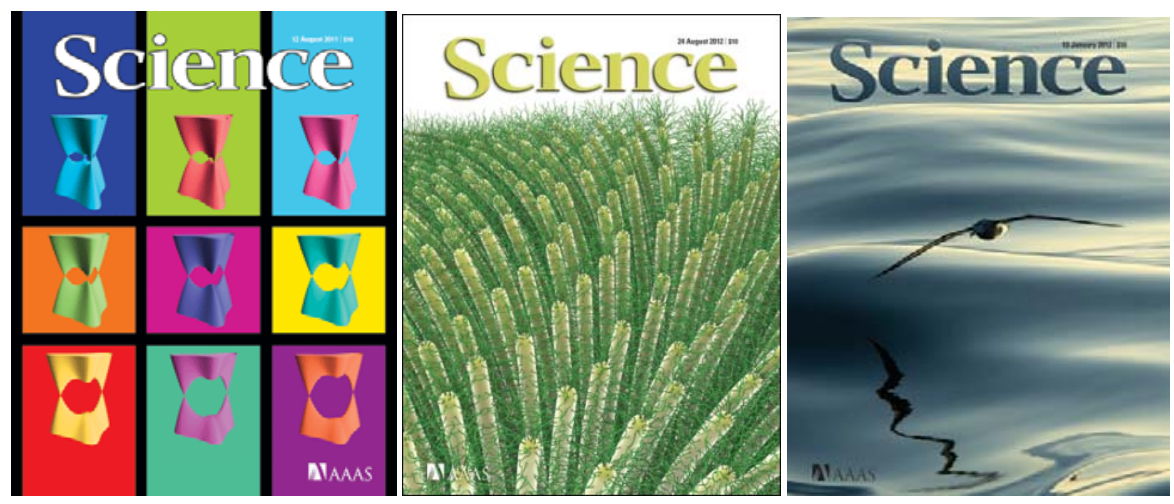

Figures $2 \mathrm{a}-\mathrm{f}$

The pictures on the covers of Science can be roughly sorted into four types that categorize the significant and reoccurring stock of the reviewed cover pictures (for a similar categorization see Liang, 2013). Firstly, one can find photographic visualizations on the covers. In this category falls photography as one can perceive with the unaided eye, such as a bird's flight (figure 2f), reflection of bottles (figure 2c) or marching soldiers (figure 2b). Secondly,-and much more frequently-one can find micro- and macroscopic photographic visualizations. Within this category are also all photographic pictures that one cannot simply see with the unaided eye, such as cellular processes (figure 2d) or images of whole galaxies (cf. Science, July $8^{\text {th }}, 2011$, Vol. 333, no. 6039). Thirdly, there are also computer software based visualizations. This category includes for example the images of cell structures with the help of 3D-computer simulations and color scheme manipulations to first and foremost make these phenomena visible at all (figure 2e). Fourthly, on some covers one can find interpretive visualizations. A phenomenon that is visually not displayable or even ever seen before is made visible through creative adaption. For an example one can look at the Science cover of the $22^{\text {nd }}$ of July 2011. There they were showing a "schematic representation of one- and twodimensional RNA nanostructures” (Liang, 2013). How should one even directly depict a onedimensional RNA nanostructure? Simply out of this reason a schematic representation is chosen that necessarily includes an interpretative intrusion. The cover of the $2^{\text {nd }}$ of April 2010 can be seen in a similar way: In this issue electrical impulse in cells are shown that in fact cannot be seen with the human eye, yet in schematic drawings can be made visible (figure 2a).

The connection of category 2 and 3 as well as 3 and 4 are the dominant visualization strategies on the Science covers between 2010 and 2013. More concretely, on these covers 
especially microscopic small or invisible items are displayed through digital manipulation (this goes for figures 2a, d and e). This result should not be so surprising. After all the Science magazine focuses its research on genetics and biotechnology (that, above all, have to do with microscopic small processes). What should, in fact, be more surprising in this list of central visualization categories is what is missing. When looking at the covers of magazines like Time or Der Spiegel (see figure 1 or even figures 7a-d) it becomes obvious: These covers display a prominent image type that is completely absent on the Science covers, namely the symbolic or allegoric visualization. So in the previously described example of a Time cover two naked people, two trees and two helix shaped bands are shown that are directly charged allegorically: Both trees refer to the biblical trees of life and the knowledge of good and evil which again is an allegory on the basic principles of human needs and existence; the naked man and woman refer to Adam and Eve which again symbolize humanity as a whole; the two helix shaped bands represent the DNA helix which is entangled with the trees of knowledge and life. This again has an allegoric meaning, through DNA analysis fundamental human characteristics become readable and changeable.

However, I am not trying to say that Time offers interpretations for certain phenomena and Science does not. Of course, there are massive interpretive invasions on the material shown also on a Science cover. But-and this is the crucial difference-the depictions are not allegorically or symbolically charged beyond that. This way the images are not as easily readable as is the case on Time covers on which the visual allegories receive clear references through text additionally. The visualizations in Science are, compared to this, not general allegories and are not semantically connected further through linguistic explanations. They remain more directly related to concrete phenomena in the world. But with this they also remain (without additional linguistic information) harder to read.

Formulated in semiotic vocabulary, this illustrates the dominance of the symbolic types of signs on the Time cover. Subjectively a meaning is connected to a sign which is regulated by conventions and charged allegorically (the tree represents the tree of knowledge which again symbolizes the thirst for knowledge of humanity and this again only becomes readable when you know about the biblical story of man being thrown out of paradise). In comparison, the Science covers work more frequently with indexical and iconic signs (for a distinction of symbol, index and icon that goes back to the semiotician Charles S. Peirce cf. Atkin, 2013). 
This means, in the case of the indexical presentation, the visualizations carry traces of their images or are causally-logically related to them. The displayed bird is a photographic trace of a bird that at some point in time existed in the world. In the case of the iconic presentation this means the depiction of cellular processes with the help of computer simulations is similar to the actual cellular processes (or at least is supposed to be). Iconic and indexical references are in contrast to symbolical ones directly motivated through the depicted subject. Thus, these signs are not arbitrarily connected to their reference. ${ }^{6}$

It should not be very surprising that the indexical and iconic sign type is predominant on the pictures on Science covers. Despite all epistemological doubts and relativisms that have shattered the modern world a central goal and promise of natural science still remains to uncover phenomena and processes of nature that are antecedent to our cognitive interest and interpretations and not (or at least not primarily) dependent on these. After all, in science it is spoken in a system-theoretical way more about truth, meaning statements about circumstances of the world that actually portray the world in a correct manner. These statements, so the maxima, should-preferablyindependent of subjective arbitrariness, opinions or allegoric interpretations-represent the circumstances of the world accordingly. Mainly for this reason, indexical and iconic presentation forms appear to be the better choice for a cover much more than the symbolic one, especially since the latter is charged allegorically. After all, this usage of signsper se offers the assumption that interpretations and even wild speculations were made up-subject and sign are only arbitrarily connected and instead of presenting actualphenomena in the world, in which entire world views should be transported (such as the Christian world view on original sin that still remains virulent in genetic research on). Thus, on the semiotic level the cover pictures of Science correspond with the systematic program of science, the search for and especially representation of truth. What could be a more 'truthful' representation of the circumstances of the world as a photographic presentation of the external reality?

Still the choice of indexical or iconic presentation forms has a certain price. It remains uncertain what exactly is being displayed or what is actually supposed to be described. Even though we are looking at concrete items of the external reality we do not exactly know what these concrete things are or what is being described by them. Formulated in a more concise way, the depicted items might be true but have no meaning (contrary to linguistic statements 
about circumstances in the world). To make this statement more plausible,one can look at the covers on the images $2 \mathrm{a}$ through $\mathrm{f}$ and question what exactly they are presenting or referring to. One should then compare the results with the linguistic explanations to the covers within the magazines. The first one is about electrical impulses, the second about altruism as hormonal effect of the hypothalamus, the third shows the reflection of bottles in order to depict the reflection effect between two mirrors through emission effects of $x$-ray beams, the fourth picture shows the surface of the hair on lung cells, the fifth makes the energy effect on different carbon isotopes visible and on the sixth cover we see an albatross above the water, the article accompanying it deals with the usage of wind changes near the South Sea through the albatross. On the covers themselves these connections are hard or even impossible to recognize. So in a way Gigante is right when she in her analysis of several Science covers speaks about a free flotation of meaning that is suggested through the images (Gigante, 2013, p. 29). The author emphasizes: "Science obviously does not choose to confer meaning on the images.” (ibid., p.23f.) As such, the cover alone does not in fact establish a definite meaning. Indeed, in most cases it even unclear what the pictures actually show.

But this uncertainty about what is being shown and the free flotation of meaning are not owed to the carelessness of the Science editorial staff. Quite the opposite,the meaning should freely float to the point of becoming irrelevant. Since the indexical and iconic presentations do not just have a tendency towards the dissolution of meaning. With this they approach a more ornamental aesthetic, meaning a presentation that abstracts from concrete items or more concisely, a presentation that shows concrete items in a way that the forms gain more importance than the actual meaning of the items. According to Immanuel Kant this transformation of perspective of a concrete item to an abstract form is the requirement for an aesthetic view of the world that Kant describes as a view of "free natural beauties" (Kant, 1914, p. 82). His example for this originates in the world of flora and fauna. In the "Critique of Judgement" Kant writes: "Flowers are free natural beauties. Hardly anyone but a botanist knows what sort of a thing a flower ought to be; and even he, though recognising in the flower the reproductive organ of the plant, pays no regard to this natural purpose if he is passing judgement on the flower by Taste.” (Ibid.)Now exchanging flowers with albatrosses, carbon isotopes or hairs on lung cells one can find exactly those 'free natural beauties' on the Science covers. 
As shown, these 'free natural beauties' are accelerated on the Science covers since the depicted is made to the undetermined (no further explanations, flight of a bird which does not emphasize which natural science principle is being discussed, schematic drawings that are so schematic that they could mean anything etc.). Thus, Kant's general thesis about products of art applies to the covers that have the free natural beauty as model. "So also delineations à la grecque [also the portrayals of the grotesque], foliage for borders or wall-papers, mean nothing in themselves; they represent nothing - no Object under a definite concept,- -and are free beauties.” (Ibid.) Exactly in this sense the pictures on the Science covers are above all one thing: free beauties that in fact have a reference to the external world, but through a play with forms make them into an aesthetic reception and through this make the question for a concrete reference irrelevant-'they represent nothing'. Now putting this into the aforementioned vocabulary of the system theory, this free beauty can be called a central means to the direct creation of affectedness. Since then the focus is more on the fascination for a sensual play with forms and removes from concrete items that fall under certain terms (be that flower, albatross or cell).

What unites the play with forms on the various covers, apart from the very different items that are displayed, is a very specific form: The items and phenomena are organized in a serial form. Serialitycan be determined as a formal structure principle where the objects identifiably repeat themselves (temporally or spacially) and with this keeping certain elements the same whilst others vary (cf. Winkler, 2008, p. 215f.). Exactly this way a series is formed. At least three subforms of seriality can be differentiated on the reviewed covers. One can find series on the covers with identical repetitions of objects with the only difference being the position on the cover, such as reflections of a bottle or a row diagram of cell structures (figures 2a and 2c). Beside this, one can find repetitions with minimal variation, such as those where the objects in a row have slight differences, like the portrayal of the hairs on lung cells that minimally bend away from each other (figures $2 \mathrm{~b}$ and $2 \mathrm{~d}$ ). Furthermore, there are also series with structural repetitions, e.g. the albatross reflects fragmented in the water and the waves carry the same curves as the albatross' wing beat (figures 2f). Independent of the particular object, the recipient is meant to be affected aesthetically through diverse serial form processes. 
Here the cover pictures follow the tradition of presentations that have mostly come from the art. Serial visualization is not a specific of natural science covers but is previously tested and traditionalized in other areas. Because of this reason one can also find the aspect of hyperconnectivity on the pictures, subsequently an affiliation to other presentation practices (in this case of art) that are understandable beyond the boundaries of one system or at least offer manifold affiliation possibilities based on a high chance of being recognized in other contexts. The artistic practices of Pop Art as well as and especially of Minimal Art have been operating with forms of seriality for at least half a century (cf. Coplans, 1968; Sykora, 1993). A very popular example of this principle is Andy Warhol's silk-screen series on "Marilyn Monroe”. Using a master drawing the individual exemplars are printed and arranged in series over and over (figure 3a). Throughout these rows the relation of identity and difference is played with since the master drawing is repeated in the individual exemplars with only a minimal variation happening every time. The pop icon Marilyn Monroe becomes a serial play of forms.In contrast to this, abstaining completely from references is Minimal Art. Here the portrayed objects are reduced (most times) to geometric figures that are (often) repeated serially. Through this reduction, along with simultaneous serial repetition, a play of forms is initiated where the viewer is directly sensually affected and motivated to appreciate the pure play with forms (figures $3 b$ and 3c).

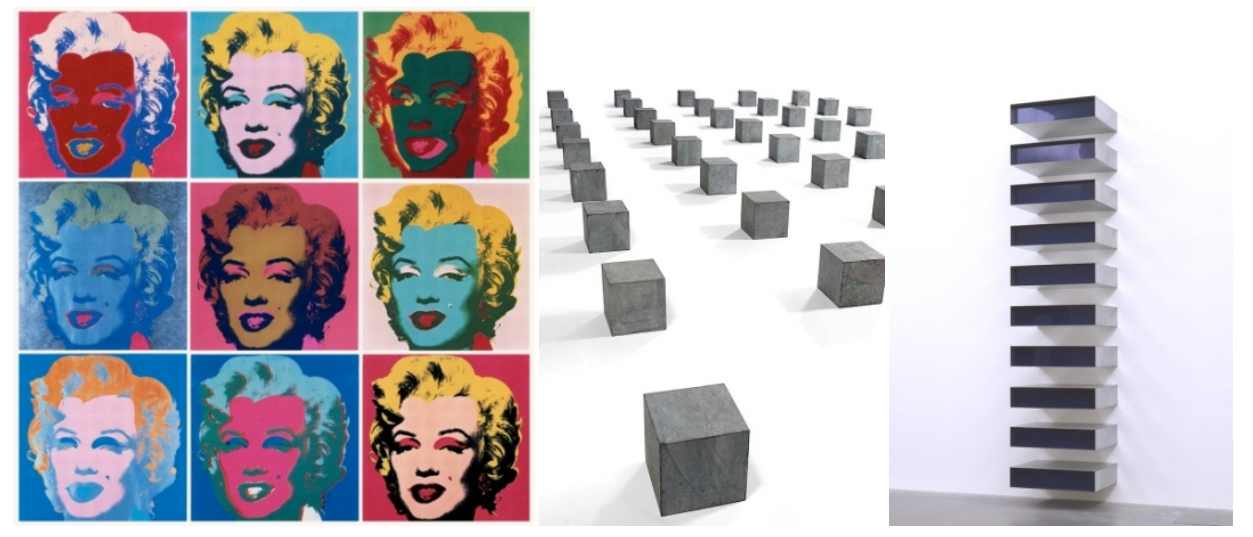

Figures $3 \mathrm{a}-\mathrm{c}$

The assumption of form principles of art are even more obvious in branch magazines of Science that concentrate on specific topics of natural science. On the covers of ScienceTraditional Medicine (figures $4 \mathrm{a}-\mathrm{c}$ ) the serial principle is not only used on the individual covers as well but the serial presentation principle itself is depicted therein. 
Subsequently,almost all covers of Science Traditional Medicineuse the same serial based presentation principle.

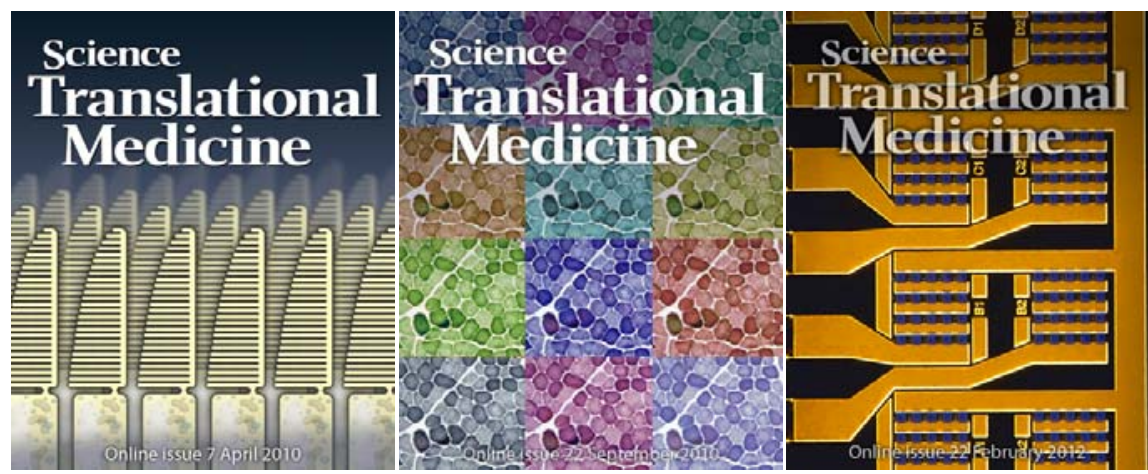

Figures $4 \mathrm{a}-\mathrm{c}$

The same goes for Science Signaling. In Science Signaling one can distinctly see that not only the serial presentation principle is put in series but the pictures on the separate covers relate to each other in similarity and this way the play with repetition and variation is carried on over various issues (figures 5a-f).

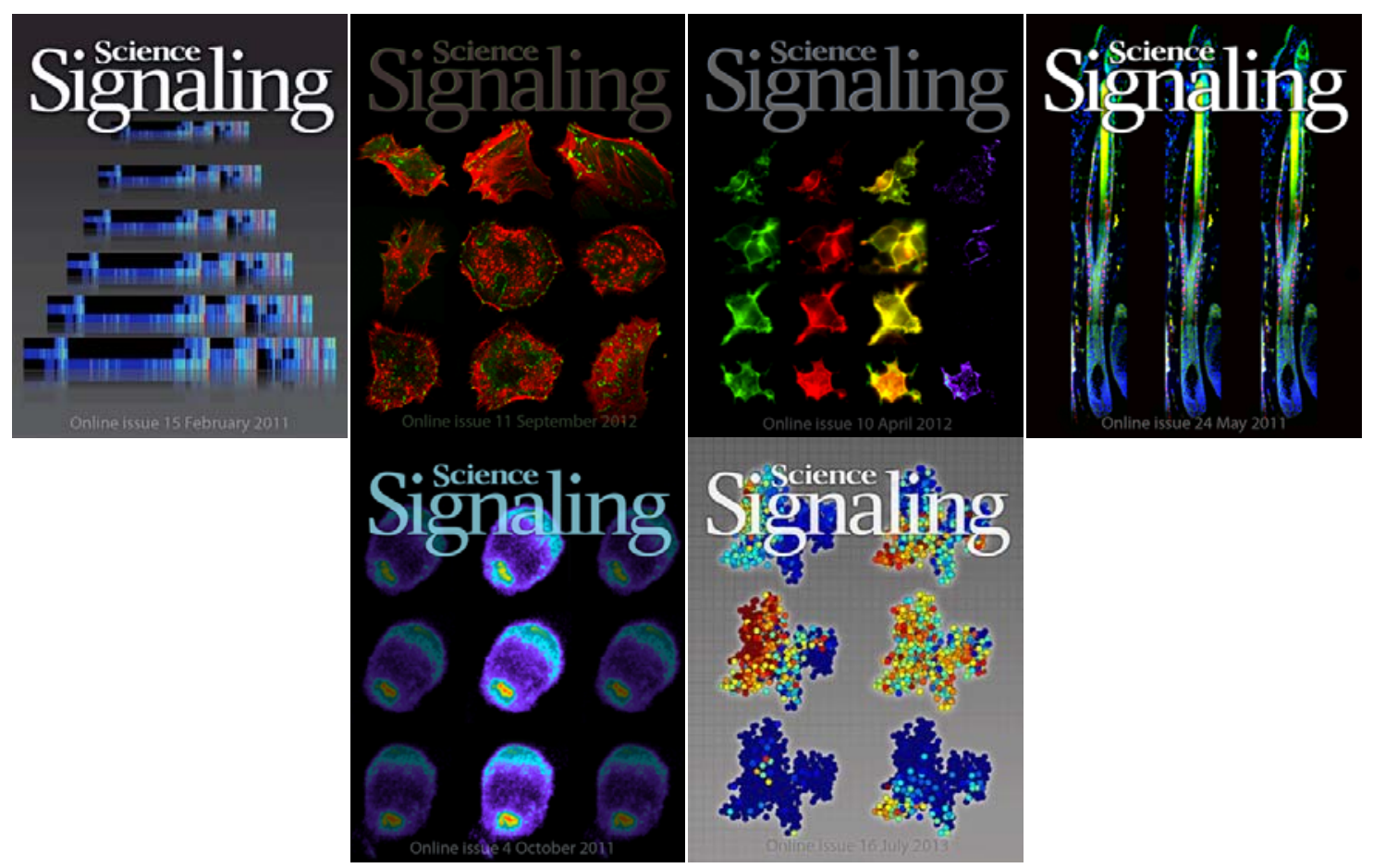

Figures 5a-f

This serial based principle becomes most clearly visible on the covers of the monthly issued nature Reviews. Nephrology which is a specialized branch of the equally popular natural 
science magazine nature based on reviews in the area of inner medicine. In this periodical an entire year shows the same picture in every issue, the only difference being the flashy coloring that varies every time (figures 6a-l).
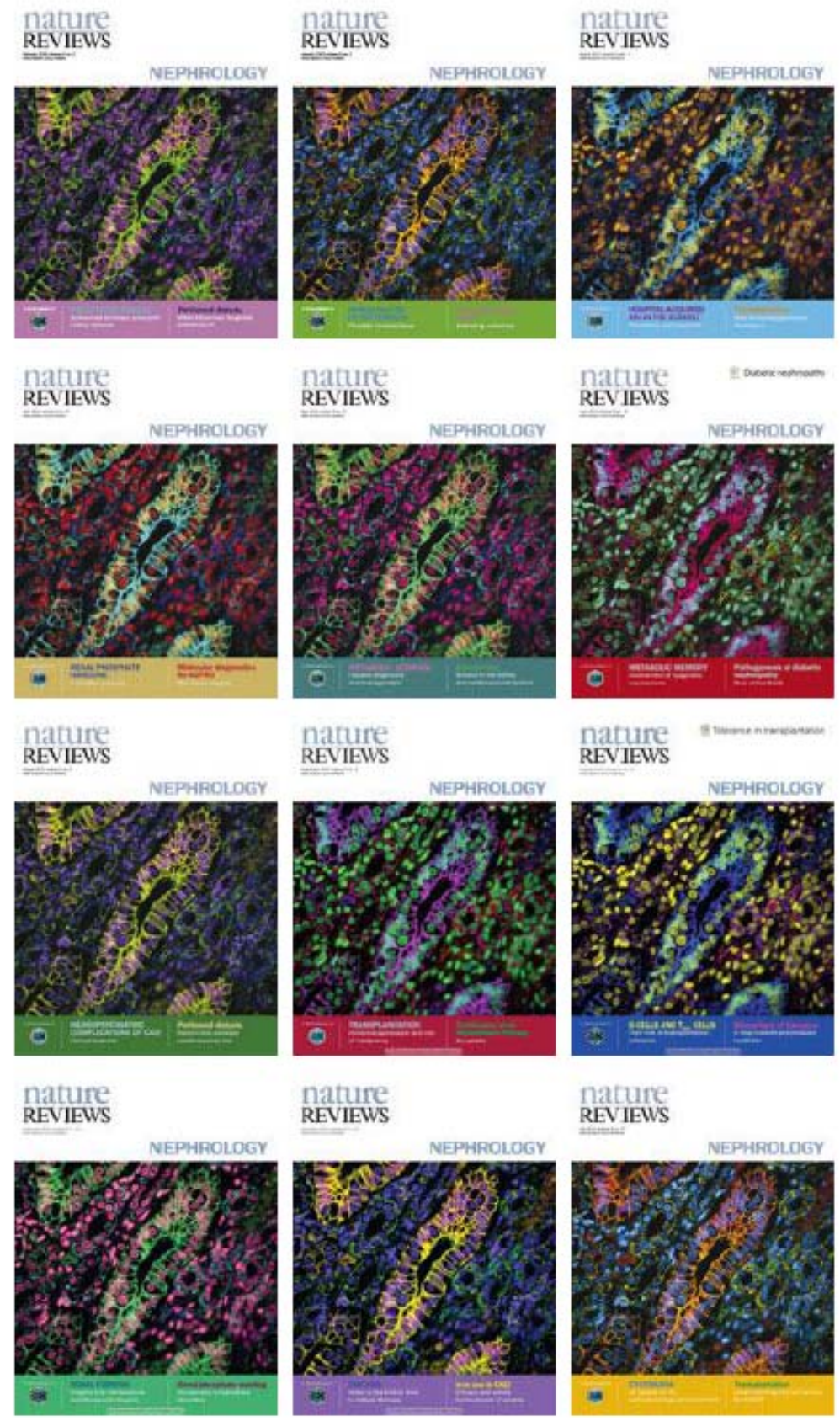

Figures 6a-l

These yearly series follow Warhol's presentation principle of the Pop Art silk-screen series to the smallest detail (repetition of a master exemplar, variation through flashy coloring).What is most visible and most extreme here is also transferable, even if only in moderate form, to the above described Science covers. These are not just serial depictions on 
individual covers, but this serial presentation principle is predominantly used on many covers, thus making it the main structure principleduring the years 2010 to 2013. Secondly, one can recognize that independent from the object being presented, the individual pictures are in a relation to similarity that can be identified as series. Some things remain the same, others vary. So, for example the cells and soldiers (figures 2a and 2b) are very similar in their arrangement. The same goes for the variations of the hairs on lung cells and the wave movement on the water which the albatross is flying over (figures $2 \mathrm{~d}$ and $2 \mathrm{f}$ ). They are alike on a formal level. This way the covers build a row of similarities being identifiable as series.

That the Science covers use aesthetic forms from the artistic area should not be understood in the manner that phenomena of natural science are transformed completely into art. Though the borrowing of artistic forms should heighten the capacity of connection, there remains a deciding difference: On the Science covers there is neither toying with models from media (as is the case in Pop Art) nor complete negation of references to circumstances of the world (as in Minimal Art). Even though the pictures tend to be perceived as pure serial play with forms, in the paratext, the elaborate picture explanations printed inside of the magazine, it is assured that they are iconic or indexical pictures that refer to circumstances of the world. Exactly this distinguishes the covers from Pop Art and/or Minimal Art: It is assured that the depicted objects refer to phenomena of the world. However, this in the paratext frequently reoccurring assurance of the worldly reference is motivated by means of creating affects on the cover even in the background-and this, by resorting to hyper-connective presentation tradition of art. Nevertheless-and this is important-despite the assurance remaining in the background, it does not disappear completely. In the context of Scienceone assumes a recipient that calculates the pictures as being iconic or indexical and referring to circumstances of the world. Because of this, there is the detailed paratext that assures the placement of the pictures being in the world in order to fall into the background when viewing the cover. Relevant remains only the principle knowledge that in fact there is such a placement. The (background) knowledge is important becausethis way the identity of the system 'science'on the cover remains intact despite the fall-back on forms of the system 'art' and the pure play with forms. Scientific pictures can be perceived this way as art but at the same time it is guaranteed that they are in fact not only art. 


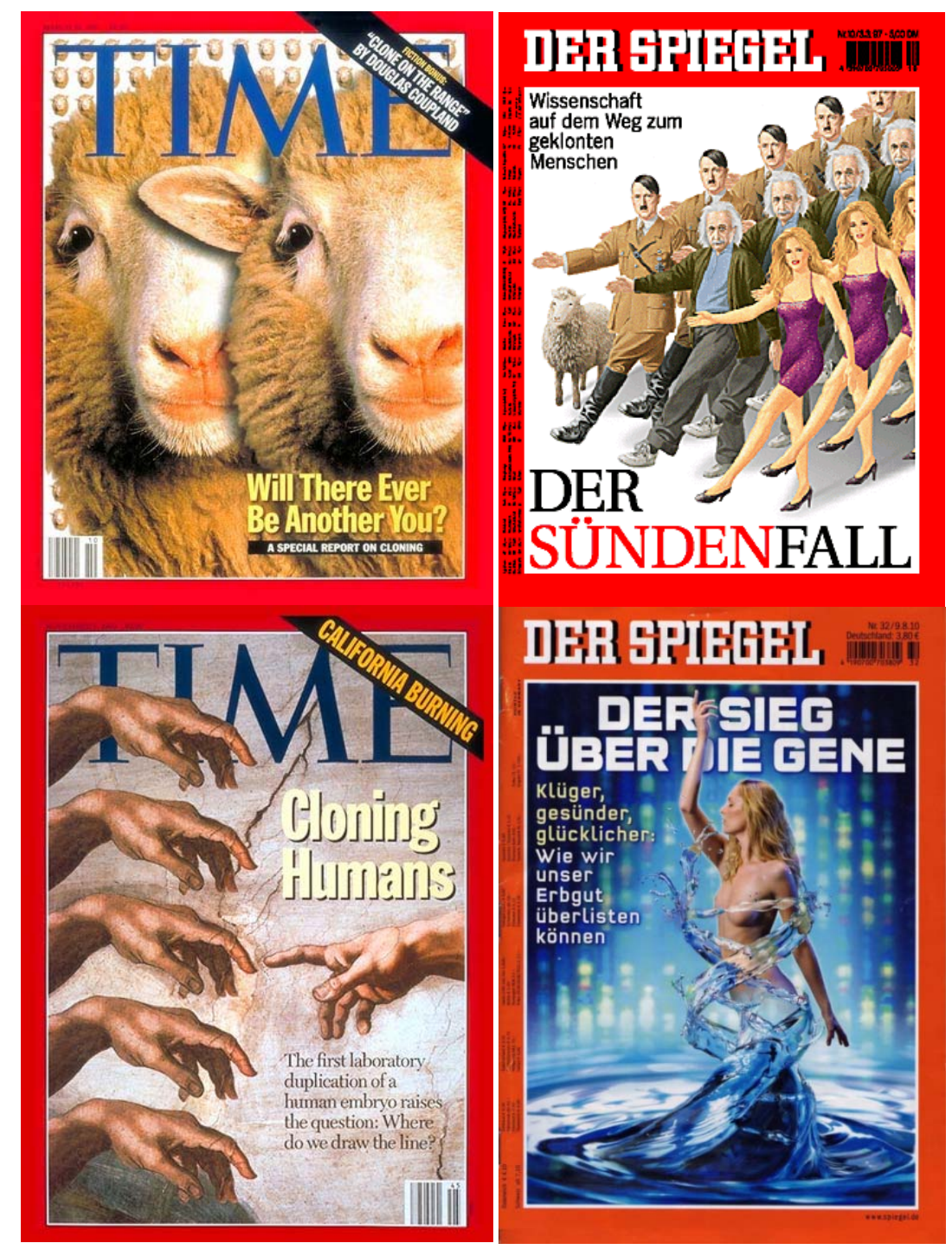

Figures 7a-d

Also, from the point of view of the system 'mass media', the specific of the cover art on the Science covers can be marked clearly through differentiation. On the covers of popular magazines such as Time or Der Spiegel one can often see forms of seriality as well (figures 7a-d). Especially with topics of the natural science, particularly cloning and genetics, the repetition principle is a common presentation form. Be it the serial principle of identical repetition (as in the case of the four times reproduction of Adam's hand on the Sistine Chapel [figure 7a] or the photographic double reproduction of Dolly, the sheep, together with Pop Art prints of Dolly in the background [figure 7b]), be it a mix of identical or varying repetition (as for example the Hitler, Einstein and Claudia Schiffer series where the individual exemplars of a person are repeated identically and the separate rows are in varying relation to one another [figure 7c]), be it structural repetitions (like a naked woman that winds 
upward in a spiral-form and whose movement adapts the spiral-formed alignment of the water [figure 7d]) or be it the order of trees that adapts the structure of the DNA helix and repeats itself (figure 1)-in all these cases forms of seriality are used. Even though the principle of series can also often be found herein (and also the reference to art presents a common operation), there still is a deciding difference to the pictures on the Science covers: All the aforementioned presentations are highly symbolic or charged allegorically with this being definitely readable and constantly holding universal meaning. It is always plain to see what is being displayed and what is portrayed inevitably means more than the simple reference to the concrete shown object. The hands of a human are Adam's hands and with this, the referenceis basically about becoming human, the clone row with Einstein, Schiffer and Hitler not only shows the possibility of human reproduction but stands for principles (science, beauty and regimes). The Science covers avoid exactly this; they are not directly allegorically interpretable, but rather refer to concrete items in the world in an indexical or iconic way and tend in contrast toTime and Der Spiegelto fade out meaning in the play with serial forms.

\section{On the Fringe: The Nature of the ScienceCover Art}

Naturally, one could pose the question why the serial presentation principle is used so excessively for the cover pictures of Science. The simplest answer would be that the actual principles of the popular take affect here. Quite obviously, the serial presentation leads to a direct affectedness of the recipient. In this way anyone can enjoy the play with forms in nature resp. natural science without previous qualifications for the most part. Furthermore, especially the serial presentation form is long since tested in art and used in many other systems (to some degree also in the system 'mass media'). The form is hyper-connective, meaning connectible and 'commonly understandable'. Both dimensions of the popular enhance the attractiveness of the system science in particular for non-scientists that in fact cannot (or do not want to) participate in the scientific discourse. Beyond this, through the assurances in the paratext as well as the iconic or indexical placement of the pictures trust is created: Science truthfully references real items of the world. In this manner one has to see this as a kind of parallel action. One can enjoy the free beauty of nature set into an artistic scene and at the same time remain convinced of the integrity of natural science resp. the magazine Science. The cover picture of natural science magazines in this light actually builds a threshold where science or even Science creates a specific picture of itself in order to (also 
and especially) become attractive for recipients outside of concrete research contexts,and this of course from issue to issue, again and again. 


\section{References}

Atkin, Albert. (2013). Peirce's Theory of Signs.InThe Stanford Encyclopedia of Philosophy.Retrieved from:http://plato.stanford.edu/archives/sum2013/entries/peircesemiotics/ [27.8.14].

Barthes, Roland. (1977). Rhetoric of the Image. In Heath, Stephen (Ed.),Image, Music, Text, (pp. 32-51). New York: Hill and Wang.

Coplans, John (Ed.). (1968).Serial Imagery. New York: Graphic Society.

Fitzpatrick, Yael. (2012).Cover Stories: Getting a New Perspective. InScience, 24 August 2012, Vol. 337, no. 6097, p. 877.DOI: 10.1126/science.337.6097.877.

Gennete, Gérard. (1997).Paratexts: Thresholds of Interpretation, Cambridge: Cambridge University Press.

Gigante, Maria Elena.(2012). Accommodating Scientific Illiteracy.Award-Winning Visualizations on the Covers of Science.InJournal of Technical Writing and Communication, Bd. 41, pp. 21-38.

Glasshoff, C. M. (2012).Why should I listen? TheEthos of science magazine covers. In2012 IEEE International Professional Communication Conference, Orlando, FL, USA, October 8-10, 2012, pp. 1-7.

Kant, Immanuel. (1914).Critique of Judgement, London: Macmillian, Retrieved from: http://lf-oll.s3.amazonaws.com/titles/1217/Kant_0318_EBk_v6.0.pdf[27.8.14].

Liang, Yan. (2013). How to make cover art for scientific journals: study existing covers and make early decisions. InL2Molecule.com. Visualize Science, Retrieved from: http://www.l2molecule.com/2013/12/20/how-to-make-cover-art-for-scientificjournals-study-existing-covers-and-make-early-decisions/ [28.6.14].

Liang, Yan. (2014). How to make cover art for scientific journals: case studies.

InL2Molecule.com. Visualize Science, Retrieved from: http://www.l2molecule.com/2014/01/22/how-to-make-cover-art-for-scientificjournals-case-studies/ [28.6.14].

Luhmann, Niklas. (2000).The Reality of the Mass Media, Stanford: Stanford University Press. Luhmann, Niklas. (2012).Theory of Society. Volume 1, Stanford:Stanford University Press. N. Matthews/ N. Moody (Eds.). (2007).Judging a Book by its Cover. Fans, Publisher, Designers, and the Marketing of Fiction, Burlington/ Hampshire: Ashgate Publish Limited. 
Nelkin, Dorothy.(2001). Molecular metaphors: the gene in popular discourse, Innature Reviews. Genetics, 2, 2001, pp. 555-559. Doi:10.1038/35080583.

Science Homepage. (2014).Retrieved from: http://www.sciencemag.org/ [27.9.14].

Stäheli, Urs.(2005). Das Populäre als Unterscheidung - eine theoretische Skizze“ [The PopularasDifference-a Theoretical Sketch]. In Pompe, Hedwig/ Jens Ruchatz (Eds.).Popularisierung und Popularität(pp. 146-167). Köln: Du Mont.

Sykora, Katharina. (1983).Das Phänomen des Seriellen. Aspekte einer künstlerischen Methode von Monet bis zur amerikanischen Popart[The PhenomenaofSerality. Aspects of Artistic Methods form Monet to American Pop Art], Würzburg: Könighausen\& Neumann.

Winkler, Hartmut. (2008).BasiswissenMedien[Basic Knowledge Media], Frankfurt am Main: Fischer. 


\section{Figures}

Figure 1: TIME: Special Report: Solving the Mysteries of DNA, 17 February 2003.

Figure 2a: $\quad$ Science, 2 April 2010, Vol. 328, no. 5974.

Figure 2b: Science, 11 June 2010, Vol. 328, no. 5984.

Figure 2c: $\quad$ Science, 4 June 2010, Vol. 328, no. 5983.

Figure 2d: $\quad$ Science, 24 April 2012, Vol. 327, no. 6097.

Figure 2e: $\quad$ Science, 12 August 2011, Vol. 333, no. 6044.

Figure 2f: Science,13 January 2012, Vol. 335, no. 6065.

Figure 3a: $\quad$ Andy Warhol: From the Series: Marylin Monroe (Marylin), 1967.

Figure 3b: $\quad$ Donald Judd: Untitled, 1980.

Figure 3c: $\quad$ Carl André: Belgica Blue Field, 1989.

Figure4a: $\quad$ Science Translational Medicine, Online Issue: 7 April 2010.

Figure 4b: $\quad$ Science Translational Medicine, Online Issue: 22 September 2010.

Figure 4c: $\quad$ Science Translational Medicine,Online Issue: 22 February 2012.

Figure 5a: $\quad$ Science Signaling, Online Issue: 15 February 2011.

Figure 5b: Science Signaling, Online Issue: 24 May 2011.

Figure 5c: $\quad$ Science Signaling, Online Issue: 4 October 2011.

Figure 5d: $\quad$ Science Signaling, Online Issue: 10 April 2012.

Figure 5e: $\quad$ Science Signaling, Online Issue: 11 September 2012.

Figure 5f: Science Signaling, Online Issue: 16 July 2013.

Figure 6a-l: nature Reviews Nephrology, 2010, Vol. 6, no. 1-12.

Figure 7a: Time: Cloning Humans, 8 November 1993.

Figure 7b: Der Spiegel: Der Sündenfall, 3 March 1997.

Figure 7c: Time: Will there be another you?, 10 March 1997.

Figure 7d: $\quad$ Der Spiegel: Der Sieg über die Gene, 9 August 2010. 


\section{Endnotes}

${ }^{1}$ The term text is used in a loose context. It not only contains written statements, but also auditive and visual ones. This way a picture can be a paratext as well (see here already Genette, 1997).

${ }^{2}$ This is so not least because of the high distribution, but even more so because of the very high impact factor of currently 31,027 in the category of multidisciplinary science. A publication in Science is extremely desirable for natural scientists.

${ }^{3}$ For one of the few exceptions see: Gigante, 2012.

${ }^{4}$ On the homepage of Science you can find a link next to the cover with the title “About the Cover” instead.

${ }^{5}$ Meanwhile this has changed. Since 2014 the cover pictures are often accompanied by short texts. This change should be further evaluated in a separate paper but goes beyond the purview of my work.

${ }^{6}$ Yet one has to relatives here: Individual signs are not exclusively sorted into one of the three mentioned types of signs; it is more about tendencies. This again means, for example, photography has an indexical, an iconic and a symbolic level. However, in the photograph depending on its context or manner of representation one type of sign is dominant. When looking at the present case the pictures on the natural science covers always also have a symbolic potential, however this is not dominant or not further charged allegorically (cf. Atkin, 2013). 